\title{
Capturing Risks and Potentials for Microfinance Sustainable Growth in Cameroon
}

\author{
Tchouassi Gérard ${ }^{1}$, Bomnsa Thaddeus Jini ${ }^{2 *}$, Balgah Roland Azibo ${ }^{3}$
}

\begin{abstract}
This study captures the relationship of risks, potentials and microfinance sustainable growth in Cameroon where growth has been particularly favored by increased unreliability of the formal banking sector. However, significant improvements currently observed in the latter sector present a new form of risk. How MFIs will survive in the face of a vibrant commercial banking sector in Cameroon is not fully researched. Empirical data from the North West region of Cameroon was purposively and randomly selected for the case study of two Microfinance institutions, CamCCUL and MUGFIC PLC. Collected quantitative data was analyzed. It was observed that CamCCUL clients were generally less exposed to risks than MUGFIC ones $(99 \%$ and $94 \%$ respectively; $\mathrm{X} 2=0.03$. On the contrary, MUGFIC generally engaged in riskier activities than CamCULL $(\mathrm{P}=0.000)$. These risks can however be significantly minimized through improved risk management strategies to further mitigate risks in the MF sector in Cameroon.
\end{abstract}

Key words: risks, potentials, microfinance, sustainable growth, poverty, Cameroon

\section{Introduction}

Throughout the world, the poor are excluded from formal financial systems. One of the most irrefutable outcomes of exclusion especially in poor countries has been the high price or outright unavailability of credit to rural communities (Sharma and Zeller, 1997). Microfinance institutions have emerged over the years as key instruments assisting many of the poor - especially women, to navigate out of poverty (Cull et al, 2009; Tchouassi, 2011). But the poor need access to financial services as a fundamental lever to escape the vicious cycle of poverty (Carter and Barrett, 2006). The Microfinance industry (MFI) emerged as a global institutional arrangement to provide access to financial services to the poor in many developing countries-particularly women, and to support them to navigate out of poverty. Similar to all financial establishments, microfinance institutions (MFIs) face risks that they must identify and manage efficiently and effectively to be successful. The key risks include; risk of high indebtedness which is linked to intense competition in many markets and those affecting day-to-day activities such as fraud (CGAP/World Bank, 2009).

The argument for high persistence of risks among MFIs especially in developing countries has been that screening potential borrowers and monitoring their behavior as

\footnotetext{
$1{ }^{1}$ Faculty of Economics and Management, Department of Economics, University of Yaoundé II, Cameroon

${ }^{2}$ Faculty of Business Administration, University Institute of International Development, University of Maroua, Cameroon.

*Corresponding author,

${ }^{3}$ Research and Development Fellow, University Lecturer, University of Bamenda, Cameroon
} 
well as enforcing credit contracts are extremely costly, given wide information asymmetry and the legal system is still very much under-developed, unreliable and inaccessible (Blondeau, 2006).

The global MF industry grew in importance in many developing countries, especially over two decades following the structural adjustment program (SAP) initiated by the Brettonwoods institutions (IFAD, 1999). The last decade has witnessed a rapid reemergence and growth in the formal banking sector resulting in increasing competition and it becomes crucial to understand how the MFIs will survive and maintain their market share in the face of an improving and re-emerging commercial banking environment. The potential and actual contributions of the microfinance sector towards development and poverty reduction especially for poor women in developing countries where formal financial markets fail or function sub-optimally have been largely emphasized in the contemporary topical literature (Tchouassi and Tekam, 2003, IMF, 2005). However, this literature is almost silent about the challenges the sector faces as a result of improvement in formal financial institutions in countries like Cameroon. This article contributes to the literature, by examining the issues based on selected case studies from Cameroon.

The main objective of this study is to estimate the risks and potentials of market sustainable growth for MFIs in contemporary Cameroon, in the backdrop of a growing formal banking sector. The study (1) describes and characterizes Microfinance clients;(2) identifies and explores risk factors for MFIs growth in Cameroon; (3) identifies existing and potential risk management strategies to ascertains contemporary growth potentials and their implications on the future of MFIs in Cameroon.

The topical literature holds that MFIs face a significantly wide number of risks that can potentially influence their sustainable growth. These risk factors are either internal or external to the MFI (Balgah, 2015, Armendariz and Morduch, 2010). The dominant risk management strategy implored by an MFI (formal or informal; preventive, mitigation, coping, adaptation/resilience) is contingent on the dominant type of risk faced by the MFI (internal or external). The level to which management strategies can moderate risks determines the outcome. These relationships are presented in figure I below. It can then be logically concluded that the outcome of MFIs is strongly contingent on the extent to which risk factors are identified and managed. An attempt is made to move along these lines to understand the growth potentials for the microfinance sector in Cameroon. 


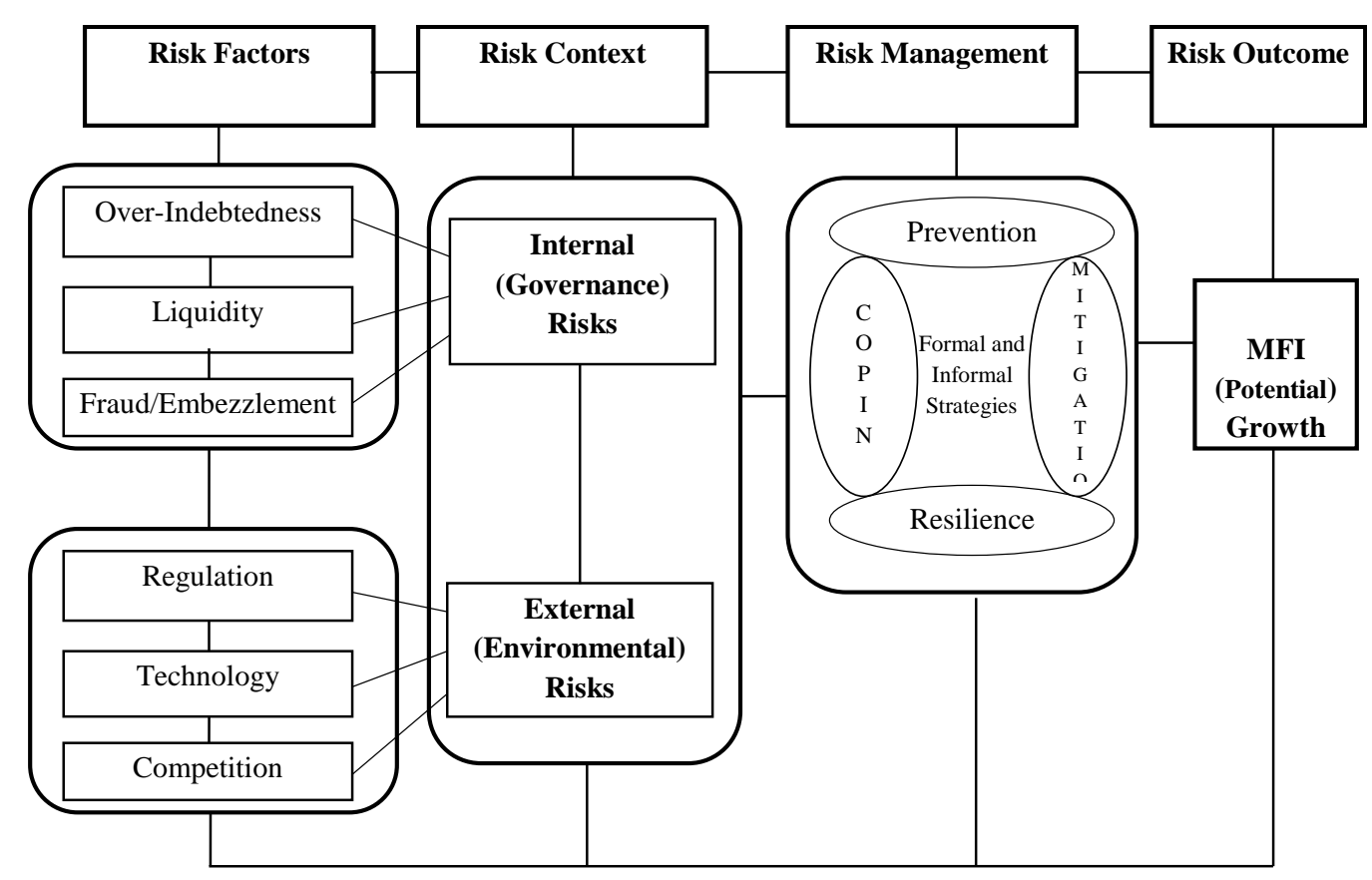

Source: Adapted From Holzmann et al (2003), CGAP/World Bank (2009) and Balgah (2015)

Figure 1: Conceptualisation risk factors and areas for Microfinance growth

\section{Review of Relevant Literature}

Globally, a brief review of the concept of microfinance seems to have emerged from various savings and credit groups and activities that have operated for centuries in many developing countries. These include for instance the susus of Ghana, chit funds in India, tandas in Mexico, arisan in Indonesia, cheetu in Sri Lanka, tontines in West Africa, pasanaku in Bolivia, njangis in Cameroon, as well as numerous savings clubs and burial societies found all over the world, just to name a few (Ledgerwood, 1999, Yaron et al 1998). Microfinance in the modern sense, dates back to the 1970 s when a new wave of microfinance initiative introduced many new innovations into the traditional, community based savings and credit sector in Bangladesh. Yunus (2003) the Nobel Peace prize winners for example, started mobilising credit groups with loan packages as small as $\$ 27$. Microfinance Institutions (MFIs) in SSA reported reaching 16.5 million depositors and 6.5 million borrowers (UN, 2013). As early as 1910 in Cameroon, French Colonial administration set basis for regulating informal financial system of traders, itinerant bankers, tontines, self-help organizations and other (Henry, A., et al.1991, Nzemen, 1998). All such development came along with risks.

The term 'risk' is used when referring to uncertain (stochastic) events whose outcomes are either known or unknown (Alwang et al. 2001, IFPRI 2002). Risk therefore refers to the prospect of a shock (Fafchamps 2003, Fischer and Buchenrieder 2010). While MFIs 
would consider strategies to minimize risks, they are only potentially harmful to the extent that they occur or not.

A critical distinction should be made between the concepts of risk, uncertainty and danger. According to Knight (1921), a risk exists only when one objectively understands and can measure its probabilistic distribution in the future. Under this constellation, a risk carries the characteristic of predictability, leading to the possibility of preventing (e.g. loan refusal), mitigating (e.g. demanding collateral) or coping (e.g. forceful recovery). A risk therefore contains quantifiable and measurable dimensions, while uncertainty is related to a large level of subjectivity, often void of any form of probability (Balgah and Buchenrieder, 2012; CGAP/World Bank, 2009). Econometric models have been developed to capture the quantitative dimensions of risks at individual, household and community levels (Fafchamps, 2003, Günther and Harttgen, 2009). These risk factors are either internal or external to the MFI (Balgah, 2015, Armendariz and Morduch, 2010).

Increasing interest in understanding and measuring risks has been demonstrated in recent years. Most often this has been done through experimental games and triangulated questioning or by directly observing qualitative or socioeconomic aspects of human behaviour (Leiserowitz 2005, Lindell and Hwang 2008). The conceptualization of risk management in Cameroon entails controlling and minimizing the losses associated with risks which might either be internal risk such as, liquidity, fraud and over indebteddness, or external risk factors which include regulation and Technology (Balgah, 2015, CGAP/World Bank, 2009, Tchouassi and Tekam, 2003)

Based on efforts seeking to determine the best way to help the poor, microfinance must be managed in a systematic manner as the industry matures further and microfinance markets become more competitive (Powers, 2005). Risk management is considered the identification, assessment, and prioritization of risks to reduce, monitor, and check the likelihood and effects of unfortunate events or to maximize the realization of opportunities (Balgah, 2015). In particular, as a result of a series of financial sector reform policies implemented in recent years there is a growing number of scholarly work exploring the link between the growth in the microfinance sector on one hand, and economic development and poverty reduction on the other hand (Adjei, 2010)

For many MFIs, growth has strained their capacity to groom new managers from within the ranks, forcing rapid promotions to fill management positions with less experience which can be exacerbated by weak human resource planning or insufficient investment in training as Molem and Mbinkar (2016) demonstrated, that the poor performance of microfinance institutions in Cameroon is caused by the poor management of resources, especially risky assets like loans. Conventional banks are unique in their risk management focus than microfinance, as is the case in Cameroon, in that they develop risk management strategies as new features in their operational growth processes (Moyi, 2016).

\section{Methodology, Sample, Data And Model}

The study aims to capture the risks and potentials for growth using CamCCUL affiliated microfinance institution and MUGFIC PLC microfinance institution as the empirical case studies. The North West Region is bordered to the North by Nigeria, to 
the South by the West Region of Cameroon, to the East by Adamawa and to the West by the South West Region (Innocent et al, 2016). Like in most regions of Cameroon, poverty remains predominantly a rural phenomenon (Tchouassi and Tekam, 2003; Innocent et al, 2016).

Temperatures vary according to seasons but mostly according to the wide topography displayed in the region, from a mean of about $15{ }^{\circ} \mathrm{C}$ in the highlands to about $27^{\circ} \mathrm{C}$ in the lowlands (Balgah and Buchnerieder, 2011, Ambagna et al, 2012). Informal micro credit and savings have traditionally been part of the financial fabric of many communities in the Northwest Region of Cameroon for a very long time. In our opinion, this region therefore presents a first choice opportunity to analyze the risks.and contains both old and newly created microfinance institutions

\section{Sampling Design and Frame}

This study adopts a cross sectional survey research design, as it is considered the most appropriate for capturing, analysing and understanding the issue of interest, that is, the risks and growth potentials for microfinance institutions in Cameroon ( Stake,R.1995). Ideally, panel or time series surveys generating data over a long period of time for all or a representative sample of MFIs all over Cameroon could produce better results. However, these types of approaches were beyond the capacity of this study, given the difficulties in getting data from the microfinance institutions; the high costs involved; and the constraint imposed by time.

The sampling for this research was both purposive and random. Only divisions where MUGFIC establishments are present were purposively selected and retained for the survey. Secondly, because of the abundance of CamCULL affiliated MFIs, those to be included in the survey were randomly selected amongst CamCULL affiliated MFIs located in the purposively selected divisions. At the level of selection of clients, purposive sampling was done two from each of the divisions to insure that top management, ordinary employees and microfinance members of sampled MFIs are included in data collection exercise

\section{Data Collection}

A questionnaire (a set of questions designed to gather information/data for analysis) was used in this study that provided answers to the research questions. Board, members and employees from 6 randomly sampled CamCCUL and 3 purposively selected MUGFIC agencies in Bui, Donga Mantung and Mezam divisions took part in the research. This explains the random and purposive selection respectively of a total of 270 clients (181 CamCCUL and 89 MUGFIC). Once in a selected institution respondents who were eligible within the designed were administered the questionnaire and interviewed on issues to further clarify perceptions. The process continued until the targeted number of respondents allocated for each institution was attain. The researcher participated in the survey which was conducted in January 2017, and personally administered a quarter of all the questionnaires in both MFIs, conducted the focused group and key informant interviews with the top-ranking executives of both MFIs. The 
rest of the questionnaires were administered by trained enumerators. In this study, 9 focus group discussions were conducted with 19 respondents from MUGFIC PLC and 37 respondents from CamCCUL institutions.

\section{Empirical Model}

There has been data transcription, coding and analysis using the Statistical Package for Social Sciences (SPSS) computer software version 20.0, as well as the Microsoft excel. Both descriptive and inferential analyses have been performed, using a 5\% confidence interval. Regression analysis has been the dominant technique used to perform the inferential analysis because risk is a probability that entails generalization, predictions and or estimations to be made from data collected from the field (Meral, U. and Yasar, A. (2012)

To estimate the strength of risk factors however, a regression analysis has been performed. The regression equation has taken the form:

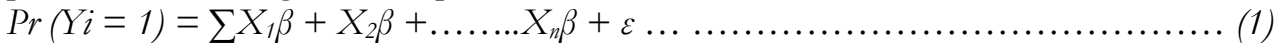

Where $\operatorname{Pr}\left(Y_{i}=1\right)$ =binary dependent variable for instance whether the microfinance institution faces any risk $(1=$ yes, $0=N o) ; X_{1}-X_{n}=$ independent/explanatory variables that explains the change $(\mathrm{s})$ in the dependent variable, for instance the different types of risks, and $\beta=$ the regression coefficients indicating the weight (importance) of say the risk, and $\varepsilon=$ the error term (Luhmann, 1993, Balgah et al, 2012)

\section{Empirical Results And Discussions}

Descriptive results on the distribution of sample population, socio-economic characteristics of clients and Micro Finance Institutions (MFIs) are presented. Analysis of risk factors that are associated with MFIs as well as the potential risk they face follows. The econometric analyses basically dwells on risk factors that positively contribute more to the risk faced by MFIs, the factors that can potentially contribute to the future growth of MFIs and the types of risk that associates strongly to MFI growth.This allowed for the capturing of the differences in perceptions among these groups. The results are presented in Figure I1 below. 


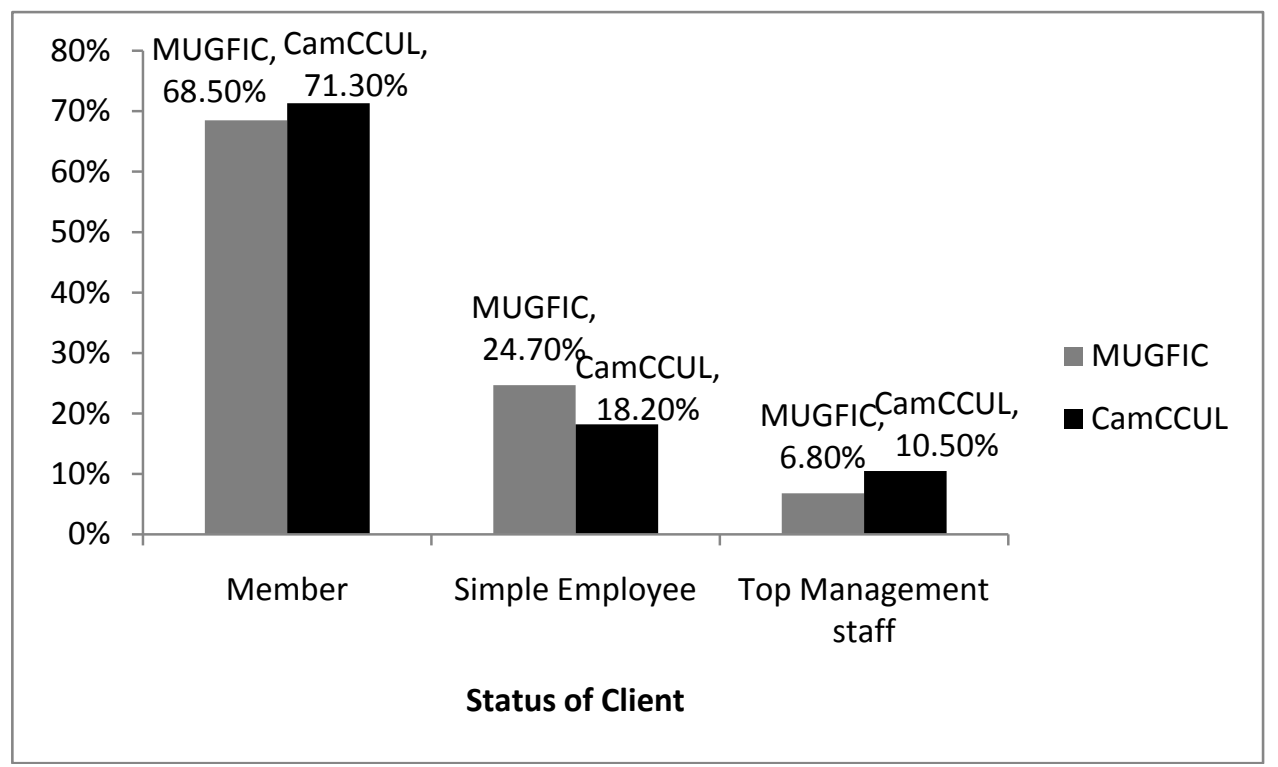

Source: Own survey data, 2017

Figure 11 Distribution of repondents by Microfinance and client type

The MUGFIC sample on the one hand was made up of $6.8 \%$ of top management respondents, $24.7 \%$ of ordinary employees and $68.5 \%$ of clients/members. The final CamCCUL sample on the other hand was made up of $10.5 \%$ of respondents from top management, $18.2 \%$ from ordinary employees, and $71.3 \%$ from clients $/$ members.

Further analysis show that the majority of the clients sampled for both the MUGFIC and the CamCCUL affiliated MFIs are male $(74.2 \%$ and $56.4 \%$ respectively. It is observed that, the percentage of female clients for the CamCCUL affiliated MFIs is greater than that for the MUGFIC MFIs (43.6\% and 25.8\%. It can therefore be hypothesized that the CamCCUL affiliated MFIs were created to target more of female clients than the MUGFIC MFIs. This is in line with Tchouassi (2012) who emphasized that understanding gender is a pre-requisite for understanding opportunities, constraints and the impacts as they affect both men and women.

\section{Risk Factors impeding MFIs Growth in Cameroon}

Respondents were asked if they feel their MFI was facing some risks that can impede their growth. More than $85 \%$ of all the clients interviewed acknowledged the fact that their MFI faces certain risk that can impede its growth. A slightly greater proportion of CamCCUL affiliated clients (91.2\%) foresaw risks, compared to $87.6 \%$ of MUGFIC clients. These risks ranged from over indebtedness, risk management, poor governance, through inadequate risk management strategies, flexible regulations, to competition and technology management. The success of MFIs in Cameroon is partly attributed to unreliability demonstrated in the late 1980s and early 1990s, and to the failure of commercial banks to provide services that are adequately tailored to the needs of the poor and women in particular. In the last decade, commercial banks have become more 
reliable and pose an eminent threat to the growth of the microfinance sector in Cameroon. This risk is likely to become more important in the future, than it is currently perceived by microfinance clients.

Table 1: Type of risk faced by MFIs

\begin{tabular}{|c|c|c|c|c|c|c|c|}
\hline Risk type & Type of MFI & $\begin{array}{l}\text { Not at } \\
\text { all }\end{array}$ & $\begin{array}{l}\text { Very } \\
\text { small }\end{array}$ & Acceptable & High & $\begin{array}{l}\text { Very } \\
\text { High }\end{array}$ & $\mathrm{X}^{2}$ \\
\hline \multirow{2}{*}{$\begin{array}{l}\text { Over } \\
\text { indebtedness }\end{array}$} & MUGFIC & $13.5 \%$ & $24.7 \%$ & $20.2 \%$ & $32.6 \%$ & $9.0 \%$ & \multirow[b]{2}{*}{0.000} \\
\hline & CamCCUL affiliated & $12.7 \%$ & $9.9 \%$ & $7.7 \%$ & $37.6 \%$ & $32 \%$ & \\
\hline \multirow{2}{*}{$\begin{array}{l}\text { Risk } \\
\text { management }\end{array}$} & MUGFIC & $16.9 \%$ & $27 \%$ & $24.7 \%$ & $21.3 \%$ & $10.1 \%$ & \multirow[b]{2}{*}{0.000} \\
\hline & CamCCUL affiliated & $11 \%$ & $12.7 \%$ & $11.6 \%$ & $30.4 \%$ & $34.3 \%$ & \\
\hline \multirow[t]{2}{*}{ Governance } & MUGFIC & $15.7 \%$ & $25.8 \%$ & $29.2 \%$ & $20.2 \%$ & $9 \%$ & \multirow[b]{2}{*}{0.002} \\
\hline & CamCCUL affiliated & $12.2 \%$ & $17.1 \%$ & $16.6 \%$ & $28.2 \%$ & $26 \%$ & \\
\hline \multirow{2}{*}{$\begin{array}{l}\text { Management } \\
\text { Strategies }\end{array}$} & MUGFIC & $13.5 \%$ & $27 \%$ & $33.7 \%$ & $20.2 \%$ & $5.6 \%$ & \multirow[b]{2}{*}{0.115} \\
\hline & CamCCUL affiliated & $11.6 \%$ & $17.7 \%$ & $28.7 \%$ & $33.7 \%$ & $8.3 \%$ & \\
\hline \multirow[t]{2}{*}{ Regulations } & MUGFIC & $14.6 \%$ & $34.8 \%$ & $28.1 \%$ & $19.1 \%$ & $3.4 \%$ & \multirow[b]{2}{*}{0.011} \\
\hline & CamCCUL affiliated & $12.2 \%$ & $20.4 \%$ & $38.1 \%$ & $16 \%$ & $13.3 \%$ & \\
\hline \multirow[t]{2}{*}{ Competition } & MUGFIC & $13.3 \%$ & $9 \%$ & $22.5 \%$ & $42.7 \%$ & $12.4 \%$ & \multirow[b]{2}{*}{0.043} \\
\hline & CamCCUL affiliated & $11 \%$ & $18.2 \%$ & $11.6 \%$ & 40.3 & 18.8 & \\
\hline \multirow{2}{*}{$\begin{array}{l}\text { Technology } \\
\text { management }\end{array}$} & MUGFIC & $13.5 \%$ & $27 \%$ & $16.9 \%$ & $27 \%$ & $15.7 \%$ & \multirow[b]{2}{*}{0.073} \\
\hline & CamCCUL affiliated & $14.4 \%$ & $18.2 \%$ & $27.6 \%$ & $31.5 \%$ & $8.3 \%$ & \\
\hline
\end{tabular}

Source: Own survey data, 2017

\section{Growth potentials for MFIs in Cameroon}

The analysis of risks faced by the case study MFIs above as perceived by clients seems to suggest that MFIs have very limited potentials for growth. But it seems logical to assume that overcoming these risks and insuring the continuous growth of the microfinance industry depends on concerted efforts between clients and the microfinance themselves. To assess this enthusiasm, clients were asked about their perceptions of the potentials for growth by their microfinance institutions.

\section{Econometric/inferencial analysis.}

The PROBIT model was deemed most appropriate based on the theoretical consideration that risk is fundamentally a probability (Knight, 1921, Luhmann, 1993, Balgah et al, 2012). This, in addition to risk perceptions captured from clients, members and managers of the selected MFIs should provide a complete picture of the risks and potentials for MF growth in Cameroon. Such complementarity is crucial for policy 
prescriptions of relevance for the growth and sustainability of the MF sector in Cameroon.

The results of the probit analysis are presented in the table below.

Table 11: Regression Estimates (dependent variable: If MFI faces risk)

\begin{tabular}{lllllll}
\hline & $\begin{array}{l}\text { Estimate } \\
\text { Risk type }\end{array}$ & $\begin{array}{l}\text { Std. } \\
\text { B-value }\end{array}$ & Error & & Sig. & \multicolumn{2}{c}{ 95\% Confidence Interval } \\
\cline { 5 - 7 } Over indebtedness & .247 & .563 & .439 & .661 & -.857 & 1.351 \\
Risk management & .070 & .507 & .138 & .890 & -.924 & 1.064 \\
Governance risk & -.774 & .471 & -1.644 .100 & -1.697 & .149 \\
Strategy & .807 & .476 & 1.694 & .090 & -.126 & 1.740 \\
PROBIT Regulation risk & -.025 & .449 & -.057 & .955 & -.905 & .855 \\
Risk of competition & -.525 & .448 & -1.171 .242 & -1.403 & .354 \\
Technology & .313 & .342 & .917 & .359 & -.357 & .983 \\
management & & & & & & \\
Intercept & -3.406 & 2.184 & -1.559 .119 & -5.590 & -1.221 \\
\hline
\end{tabular}

a. PROBIT model: PROBIT $(p)=$ Intercept $+B X$

Source: Own survey analysis, 2017

Looking at the $\mathrm{Z}$ or estimated B-values from the table above, we observe that over indebtedness, failure to manage risk, their strategies as well as their level of technological management positively correlates with the level of risk faced by both MFIs. On the other hand, the governance risk, regulation risk and the risk from competition appear to have negative contributions to the risk faced by these MFIs. Looking at the $\mathrm{Z}$ values, the MFI strategies contribute the largest in terms of risk faced by the MFIs that can impede growth of MFI (1.694, P = 0.090). Though not significant at the 5\% level, the MFI strategies are significant at the $10 \%$ level in affecting future growth. From the above table, the regression equation can be written as;

$\operatorname{Pr}(Y i=1)=0.807$ strategy +0.313 technology management +0.247 over indebtedness + 0.070 risk management $-3.406 \ldots \ldots \ldots \ldots \ldots \ldots \ldots \ldots . .2$

\section{Conclusion and Recommendations}

Empirical literature holds that throughout the world, the poor have generally been excluded from sufficient access to financial services from formal financial institutions. (Sharma and Zeller, 1997, Tchouassi and Tekam, 2003). There is a need to develop financial institutions and services that are well tailored to the specific needs of the poor (Tchouassi, 2011). The main objective of this paper is crucial to identify potential risks faced by CamCCUL and MUGFIC MFIs in the market of sustainable growth process of contemporary Cameroon. To achieve this objective, about $85 \%$ of all the clients interviewed acknowledged the fact that their MFI faces certain risk that can impede its growth. CamCCUL affiliated clients $(91.2 \%)$ foresaw risks, compared to 
$87.6 \%$ of MUGFIC clients where sustainability has been further strengthened by the failure of the formal financial sector between 1980s and 1990s in many African countries (Yaron, 1994). Analysis of field data leads to the conclusions that the risks faced by CamCCUL establishments where savings is significantly higher seem to be lower than those faced by MUGFIC ones $\left(99 \%\right.$ and $94 \%$ respectively; $\left.X^{2}=0.03\right)$. MUGFIC establishments were rather found to engaging in riskier activities (such as pension scheme, overdraft) than CamCUL institutions. All the MFIs have adopted some strategies to manage current and potential risks with MUGFIC clients $(32.6 \%)$ than CamCCUL affiliated clients $(18.2 \%)$ reported flexibility and leniency in the loan award process. We therefore conclude that in spite of all the risks, there are still potentials for microfinance sustainable growth in Cameroon

Based on the above analysis, we recommend that; where CamCCUL have registered better performance, MUGFIC and others should continuously re-ploughed back into their respective MFIs to reduce chances of insolvency and increase their growth potentials, increasingly employ qualified and committed staff as well as, create more branches in ruaral areas which are unattractive to Commercial banks.

\section{References}

Adjei, J. (2010). Microfinance and Poverty Reduction: The Experience of Ghana, Accra: BOLD Communications Limited

Alwang, J., Siegel, P. and Jorgensen, S. (2001), Vulnerability: A view from different disciplines. Social Protection Discussion paper No. 0115, The World Bank.

Ambagna, J., Kane, G. and Oyekale, S. (2012). Subsistence farming and food security in Cameroon: A macroeconomic approach, Life Science Journal 9(4), 3949-3954.

Armendáriz B. and Morduch, J. (2010), The economics of microfinance, second edition: Library of Congress Cataloging-in-Publication Data, United States of America

Balgah, R. A. (2015). A Novel Framework for Analyzing Idiosyncratic And Covariate Shocks In Developing Countries. WIT Transactions on The Built Environment, 168, 1123-1134.

Balgah R. et al (2016) Contribution of Mushroom to Actor's Income in the North West Region, Cameroon: A Value Chain Analysis, International Journal of Agriculture and Forestry,pp. 206213,http://journal.sapub.org/ijaf

Balgah, R.A. and Buchenrieder, G. (2012). Risk, uncertainty and decision making. An empirical investigation of Irving Fischer's theory of interest. Global Advanced Research Journal of Peace, Gender and Development Studies 1(2), 033-41.

Blondeau, N (2006) La microfinance Un outil de développement durable? «Études ».pp 188- 198. https://www.cairn.info/load_pdf.php

Carter M. and Barrett C. (2006), 'the economics of poverty traps and persistent poverty: an asset-based approach', Journal of Development Studies 42 (2): 178-199.

CEMAC (2006. CEMAC Region Financial Sector Assessment Program, Technical Note, Access to Finance

CGAP/World Bank (2009). Operational risk management for microfinance institutions. Washington DC: CGAP/ The World Bank.

Cull, R., Demirgüc-Kunt, A, and Morduch, J. (2009b), Microfinance meets the market, analysis of Banco Compartamos of Mexico, The Journal of Economic Perspectives, 23 (1), 167-192.

Fafchamps, M. (2003). Rural Poverty, Risk and Development. Edward Elgar Publishing Limited, Cheltenham, United Kingdom

Fischer, I. and. Buchenrieder, G. (2010). Risk management of vulnerable rural households in Southeast Asia. Ninth European IFSA Symposium on: Building sustainable rural futures. The added value of systems approaches in times of change and uncertainty, July 4-7, 2010. 
Günther, I. and Harttgen, K. (2009). Estimating household vulnerability to idiosyncratic and covariate shocks. A novel method applied in Madagascar. World Development, 37 (3), 1222-1234.

Henry, A., et al. 1991 Tontines et banques au Cameroun. Les Principes de la Société des Amis. Paris: Karthala

Hsiao C. (1996) Logit and Probit Models. In: Mátyás L., Sevestre P. (eds) The Econometrics of Panel Data. Advanced Studies in Theoretical and Applied Econometrics, vol 33. Springer, Dordrecht

IFAD (1999), Cameroon National Microfinance Support Program Inception Report, IFAD Africa 1 Division (Unpublished 1999)

IMF, (2005). Microfinance: A View from the Fund, IMF, Washington DC.Intrahousehold Resource Allocation, Quarterly Journal of Economics, Vol. 117(3): 962-995

IFPRI (2002). Background information for presenters in improving understanding of risks and household responses to risk, Paper presented at the World Bank Conference on 'Risk and Vulnerability: Estimation and Policy implications'. IFPRI, Washington DC, 23 and 24 September.

Innocent, N., Bitondo, D. and Balgah, A. (2016). Climate Variability and Change in the Bamenda Highlands of North West Cameroon: Perceptions, Impacts and Coping Mechanisms, British Journal of Applied Science and Technology, 12 (5), 1-8.

Kamberelis, G and Dimitriadis, G (2005). 'Focus groups: Strategic articulations of Pedagogy, politics, and inquiry', in N Denzin \& Y Lincoln (eds), The SAGE handbook of qualitative research, 3rd edn, Sage Publications, Thousand Oaks, California, pp. 887-907.

Knight, F. (1921). Risk, Uncertainty and Profit. New York: Harper.

Ledgerwood, J. (1999), Microfinance handbook, an institutional and financial perspective, Washington DC; The World Bank

Littlefield, E., Morduch, J., \& Hashemi, S. (2003). Is microfinance an effective strategy to reach the Millennium Development Goals? Focus Note, 24(2003), 1-11

Leiserowitz, A. (2005). American Risk Perceptions: Is Climate Change Dangerous? Risk Analysis, 25 (6), 1433-1422.

Lindel, M. and Hwang, S. (2008). Household's perceived personal risk and responses in a multihazard environment. Risk Analysis, 28(2), 539-556

Meral, U. and Yasar, A. (2012) A Case Study of Probit Model Analysis of Factors Affecting Consumption of Packed and Unpacked Milk in Turkey, Economics Affecting Consumption of Packed and Unpacked Milk in Turkey., Department of Agricultural Economics, Faculty of Agriculture, Gaziosmanpasa University, Tokat, Turkey

Nzemen, M. (1998), Théorie de la pratique des tontines au Cameroun SOPECAM, Yaoundé, 163p

Otero.M. (1999)Bringing development back, into microfinance Journal of Microfinance/ ESR Review, journals.lib.byu.edu

Sharma, M. and Zeller, M. (1997), Repayment performance of group-based Credit programs in Bangladash: An empirical analysis, World Development 25 (10), 1731-1742.

Stake, R. (1995). The art of case study research. Thousand Oaks, CA: SAGE

Tchouassi, G. (2011), Microfinance, inequality and vulnerability: Empirical analysis from Central African countries, Journal of Development and Agricultural Economics 3(4), 150-156

Tchouassi, G. and Tekam, O. (2003), Microfinance et reduction de la pauvreté, le cas du credit du Sahel au Cameroun. Revue International de l'economie Sociale 288, 80-88.

UN (2013) Microfinance in Africa, Overview and Suggestions for Action by Stakeholders,

The United Nations, Office of Special Adviser on Africa.

Yaron, J. (1994), What makes rural finance markets successful? World Bank Research Observer, 49-70

Yaron et al.(1998), Rural Finance: Issues, Design and Best Practices: Part One, E.Coffey, Agricultural Finance: Getting the Policies Right: Part One, FAOYin,R. (1994) Case study research: Design and methods (2nd ed.) Thousand Oaks: Sage Publication

Yin, R. (2003). Case study research: Design and methods (3rd ed.) Thousand Oaks: Sage Publication.

Yunus, M. (2003). Banker to the Poor: Micro-Lending and the Battle against World Poverty https://www.scribd.com/doc/72971057/List-of-Books-on-Micro-Finance 
